\title{
PENGEMBANGAN VIDEOSCRIBE BERFIKIR SIMBOLIK REPRESENTASI BERBAGAI MACAM BENDA PADA KELOMPOK ANAK USIA 5-6 TAHUN DI PAUD LAB ANANDA CITRA BAKTI
}

\author{
Gde Putu Arya Oka ${ }^{1)}$, Ferdinandus Bate Dopo ${ }^{2)}$ \\ ${ }^{1,2)}$ Dosen STKIP Citra Bakti \\ email: aryaoka@citrabakti.ac.id
}

\begin{abstract}
Abstrak
Penelitian ini merupakan penelitian Desain dan Pengembangan (Design \& Development Research, DDR). Tujuan pengembangan adalah untuk mengetahui tingkat kelayakan videoscribe berfikir simbolik berbagai macam benda pada kelompok anak usia 5-6 tahun. Model pengembangan mengadopsi kerangka model pengembangan produk multimedia pathways Cathie Sherwood. Tahapan multimedia patways terdiri dari (1) initiation, (2) specification, (3) design, (4) production, (5) review and evaluation dan (6) delivery and implementation. Metode analisis data menggunakan analisis deskriptif kuantitatif dan kualitatif. Adapun hasil pengembangan adalah produk videoscribe yang telah diuji dengan parameter hali isi, media dan desain pembelajaran. Analisis draft I pengembangaan dengan tingkat pencapaian kualitas isi videoscribe sebesar 92\%, setelah dikonversi berada dalam kualifikasi Sangat Baik. Kemudian Analisis draft II pengembangan dengan tingkat pencapaian kualitas media videoscribe sebesar $90 \%$, setelah dikonversi berada sangat baik. Begitupun tingkat pencapaian kualitas desain pembelajaran videoscribe sebesar $94,67 \%$, setelah dikonversi berada dalam kualitas sangat baik. Sedangkan analisis draft III pengembangan, tingkat pencapaian kualitas dalam uji perseorangan sebesar $93 \%$. Setelah dikonversi berada dalam kualifikasi sangat baik. Begitupun tingkat pencapaian kualitas videoscribe dalam uji kelompok kecil sebesar $88 \%$ dan setelah dikonversi berada dalam kualifikasi juga baik. Dengan demikian, mengacu pada parameterparameter diatas maka dapat disimpulkan pengembangan videoscribe berfikir simbolik representasi berbagai macam benda untuk anak usia dini 5-6 tahun layak untuk diimplementasikan dalam pembelajaran anak usia dini, khususnya untuk mencapa Kompotensi Dasar (KD) 3.3, 3.5, 3.6 dan 3,9 .
\end{abstract}

Kata kunci: pengembangan videoscrbe, berfikir simbolik, AUD 5-6 tahun,

\begin{abstract}
This research is a Design \& Development Research (DDR). The purpose of the development is to determine the feasibility of videoscribe to symbolic thinking of various objects in the group of children aged 5-6 years. The development model adopts Cathie Sherwood's pathway for multimedia product development model frameworks. The stages of multimedia patways consist of (1) initiation, (2) specification, (3) design, (4) production, (5) review and evaluation and (6) delivery and implementation. The method of data analysis uses quantitative and qualitative descriptive analysis. The results of the development are videoscribe products that have been tested with content, media and learning design parameters.
\end{abstract}


Analysis of draft I development with the level of achieving video quality content of $92 \%$, after being converted is in a Very Good qualification. Then Analysis II draft development with the level of achieving video quality video subscription by $90 \%$, after being converted is very good. Likewise the level of quality achievement of videocribe learning design is $94.67 \%$, after being converted it is in very good quality. While the analysis of draft III development, the level of quality achievement in individual tests was $93 \%$. Having converted is in very good qualifications. Likewise, the level of achieving videocribe quality in the small group test was $88 \%$ and after being converted was also in good qualifications. Thus, referring to the parameters above, it can be concluded that the development of videoscribe to think symbolic representations of various objects for early childhood 5-6 years is feasible to be implemented in early childhood learning, especially to achieve Basic Compotence (KD) 3.3, 3.5, 3.6 and 3.9

Keyword: videoscribe development, symbolic mindset, AUD 5-6 Tahun

\section{PENDAHULUAN}

Tujuan penyelenggaran PAUD Nasional sebagaimana tertuang dalam Permendikbud Nomor 146 Tahun 2014 tentang Kurikulum Satuan PAUD dinyatakan bahwa Pendidikan Anak Usia Dini, merupakan suatu upaya pembinaan yang ditujukan kepada anak sejak lahir sampai dengan usia 6 (enam) tahun yang dilakukan melalui pemberian rangsangan pendidikan untuk membantu pertumbuhan dan perkembangan jasmani dan rohani agar anak memiliki kesiapan dalam memasuki pendidikan lebih lanjut, Begitu juga peraturan Mendikbud Nomor 84 Tahun 2014 tentang Pendirian Satuan PAUD, menyatakan batasan yang sama dengan Permendibud Nomor 146 tahun 2014. Sedangkan jika membaca Perpres No 60 Tahun 2013 tentang PAUD Holistik ditemukan batasan Anak usia dini adalah anak sejak janin dalam kandungan sampai dengan usia 6 (enam) tahun yang dikelompokkan atas janin dalam kandungan sampai lahir, lahir sampai dengan usia 28 (dua puluh delapan) hari, usia 1 (satu) sampai dengan 24 (dua puluh empat) bulan, dan usia 2(dua) sampai dengan 6 (enam) tahun. Adanya perbedaan batasan PAUD dalam takaran deregulasi, membuktikan adanya ketidakharmonisan dalam peraturan yang dibuat.

Terlepas dari disharmoni kedua peraturan diatas, dalam Permendikbud Nomor 137 Tahun 2014 tentang Standar Tingkat Pencapaian Perkembangan Anak Usia Dini selanjutnya disebut STPPA disebutkan bahwa, kriteria tentang kemampuan yang dicapai anak pada seluruh aspek perkembangan dan pertumbuhan, mencakup aspek nilai agama dan moral, fisik-motorik, kognitif, bahasa, sosial-emosional, serta seni. Oleh karena sumber daya manusia yang sehat, cerdas, dan produktif merupakan aset yang 
sangat berharga bagi bangsa dan negara Indonesia, maka sangat perlu dikembangan pola pendidikan yang holistik integratif. Oleh karena itu, peningkatan kualitas sumber daya manusia harus mulai dari kualitas perkembangan anak dimasa anak usia dini. upaya-upaya yang dapat dilakukan adalah dengan peningkatan kesehatan, gizi, perawatan, pengasuhan, perlindungan,kesejahteraan, dan rangsangan pendidikan yang dilakukan secara simultan, sistematis, menyeluruh, terintegrasi, dan berkesinambungan. Disamping itu jaminan kualitas juga sangat ditentukan dengan implementasi standar-standar yang menjadi acuan dalam penyelenggaraan pendidikan anak usia dini. Standar itu seperti, (1) standar Tingkat Perkembangan Anak Usia Dini, (2) standar isi, (3) standar proses, (4) standar penilaian, (5) standar pendidikan dan tenaga kependidikan, (6) standar sarana dan prasarana, (7) standar pengelolaan, dan (8) standar pembiayaan. Terkait dengan penelitian pengembangan ini, sasaranya adalah dalam upaya memberikan variasi rangsangan dengan teknologi yang memungkinkan (technology enable) dan pemenuhan standar proses dan sarana prasarana sehingga prinsip pembelajaran PAUD akan semakin terpenuhi dan berkualitas.

Lingkup perkembangan anak usia dini kelompok 5-6 tahun, terutama kelompok B sesuai STTPA terdiri dari 6 lingkup perkembangan. Lingkup itu adalah (1) nilai agama dan moral, (2) fisik motorik yang terdiri dari perkembangan fisik morotik kasar, fisik morotik halus, kesehatan dan perilaku keselematan, (3) kognitif, yang terdiri dari belajar pemecahan masalah, berfikir logis, berfikir simbolik, (4) bahasa, yang terdiri dari memahami bahasa, mengungkapkan bahasa dan keaksaran, (5) sosial emosional yang tediri dari kesadaran diri, tanggung jawab terhadap diri sendiri dan orang lain, dan perilaku prososial, (6) lingkup perkembangan seni yang terdiri dari anak dapat menikmati alunan lagu dan suara dan tertarik dengan kgiatan seni.

Pada lingkup perkembangan kognitif, khususnya sub perkembangan berfikir simbolik anak usia 5-6 tahun, harus mencapai tingkat perkembangan dalam hal, (1) mampu menyebutkan lambang bilangan 110, (2) menggunakan lambangn bilangan untuk menghitung, (3) mencocokan bilangan dengan lambang bilangan, (4) mengenal berbagai lambang huruf vokal dan konsonan, (5) merepresentasikan berbagai macam benda dalam bentuk gambar atau tulisan, misalnya gambar pensil diikuti tulisan pensil.

Berdasarkan observasi, wawancara dan visitasi lapangan ke Lab PAUD Ananda Citra Bakti, khususnya pada kesedian alat permainan edukatif dan media 
pembelajaran yang sesuai dengan lingkup perkembangan kognitif ditermukan beberapa masalah sebagai berikut. (1) pengadaan alat-alat permainan edukatif sesuai dengan model-model pembelajaran yang akan dikembangkan, sangat sulit diperoleh dipasaran. Hal ini diperkirakan jarangnya toko yang menjual dan alasan geofrafis, (2) alat permainan edukatif yang dijual dipasaran kerap tidak sesuai dengan kebutuhan, (3) ragam jenis alat permainan edukatif sangat terbatas, (4) belum ada media edukasi yang memanfaatkan teknologi yang dirancang sesuai dengan kebutuhan anak paud, (5) media pembelajaran yang ada dipasaran kebanyakan by utilization, artinya pengelola satuan PAUD membeli lalu menggunakannya, (6) belum ada media pembelajaran yang sengaja dirancang (by design) untuk anak usia dini.

Dari hasil visitasi dilapangan, dapat di ikhtisiarkan bahwa media pembelajaran untuk mencapai tingkat perkembangan, khususnya lingkup perkembangan kognitif berfikir simbolik, belum ditemukan media yang dapat digunakan oleh guru selama proses pembelajaran anak usia dini. Oleh karena itu, jika media pembelajaran pada lingkup perkembangan kognitif berfikir simbolik tidak tersedia, hal ini akan berdampak pada terganggungnya proses belajar, tidak tercapainya tingkat perkembangan sesuai yang diharapkan dan prinsif-prinsip pembelajaran anak usia dini tidak mampu dijalankan dengan optimal.
Dengan demikian, pengembangan media khususnya videocribe sebagai media pembelajaran anak usia dini sangat mendesak untuk dikembangkan.

Pentingnya pengembangan media pembelajaran anak usia dini, khususnya dengan format media video, karena (1) belajar adalah proses internal dalam diri manusia maka guru bukan satu-satunya sumber belajar (AECT, 1994), (2) ada beberapa komponen belajar seperti pesan, orang, isi/materi/bahan, teknik/metode, alat dan lingkungan yang harus ada dalam proses pembelajaran, (3) proses pembelajaran di anak usia dini didasarkan pada prinsif kecukupan jumlah, jenis dann variasi media pembelajaran (permendikbud, 137 Tahun 2014), (4) prinsip pembelajaran PAUD untuk memanfaatkan media pembelajaran, sumber belajar agar pembelajaran bermakna dan kontekstual (permendikbud 146, tahun 2014), (5) pengembangan media video karena kontribusinya dalam hal: memperjelas pesan agar tidak terlalu verbal, mengatasai ruang dan jarak serta waktu, menimbulkan gairah belajar, memungkinkan anak belajar mandiri dan memberikan ransangan yang sama, (6) Brame (2016) dalam penelitianya menyimpulkan video mampu meningkatkan pembelajaran dan keterlibatan siswa, (7) Giannakos (2013) dalam penelitiannya juga menyimpulkan bahwa siswa lebih mudah memahami materi video 


\section{dalam domain prosedur dibandingkan media teks.}

Ada tiga jenis penelitian pengembangan, yaitu: penelitian pengembangan (developmental research), Penelitian dan Pengembangan (Research \& Development disingkat R\&D), dan Design and Development Research (Richey dan Klein, 2007). Pada saat ini arah penelitian pengembangan sedang menuju ke Design and Development Research. Richey dan Klein (2007) memaparkan Design and Development Research sebagai berikut. The systematic study of design, development and evaluation processes with the aim of establishing an empirical basis for creation of instructional and instructional products and tools and new or enhanced models that govern their development. Pada penelitian pengembangan dan desain (DDR) menurut Richey, ada dua tipe dalam DDR, yakni: (1) pengembangan produk, tools dan model dan (2) pengembangan proses. Contohnya, pengembangan sebuah "MODEL". Model disini adalah model pembelajaran. Model dalam konteks pembelajaran adalah pengembangan sebuah model untuk pembelajaran, seperti halnya Dick \& Carey mengembangkan model "desain pembelajaran" atau Chatie Sherwood mengembangkan sebuah model Pengembangan Produk.

Dalam domain pendidikan, penelitian dan pengembangan adalah suatu proses dalam mengembangkan dan memvalidasi produk-produk pendidikan (Ditnaga-Dikti, 2007 dalam Oka, G. P. A.; 2011). Karakteristik penilitian dan pengembangan terdiri atas (1) produk yang dikembangkan didasarkan pada masalah dalam pembelajaran, (2) menggunakan hasil penelitian yang relevan untuk mengembangkan produk, melakukan uji coba produk dan uji coba lapangan, (4) melakukan revisi sesuai kreteria dan tujuan yang telah ditentukan, (5) tidak menguji teori, namun mengembangkan dan menyempurnakan produk dan (6) produk yang dihasilkan bermanfaat untuk perbaikan/peningkatan kualitas pembelajaran.

Produk yang dihasilkan dalam penelitian pengembangan adalah produk yang memiliki kreteria seperti: (1) produk sesuai dengan kebutuhan pendidikan/masalah pembelajaran; (2) spesifikasi produknya jelas; (3) produk dapat dikembangkan dengan waktu dan dana yang tersedia (Ditnaga-Dikti, 2007 dalam Oka, G. P. A.:2011). Sedangkan jenis produk yang dikembangkan seperti: (1) alat peraga; (2) media pembelajaran elektronik dan non-elektronik; (3) prototipe dan simulator (bisa berbentuk software), bahan ajar elektronik dan non elektronik; (4) model pembelajaran/tutorial, dan Instrumen asessmen (DitnagaDikti, 2007).

Penelitian dan pengembangan atau Research \& Development (RD) menggunakan metologi yang membuat tiga komponen, yaitu: (1) 
model pengembangan, (2)

prosedur pengembangan dan (3) validasi produk. Sugiyono (2009) memaparkan langkah-langkah R\&D dengan tahapan, (1) adanya potensi dan masalah; (2) pengumpulan data; (3) desain produk; (5) validasi desain; (6) revisi desain; (7) uji coba produk; (8) revisi produk; (9) uji coba pemakaian; (10) revisi produk dan (11) produksi missal. Sedangkah langkah spesifik DDR adalah Analisis, Desain, Pengembangan dan Evaluasi (Richey, 2007).

\section{Standar Tingkat Perkembangan Anak (STPPA) dan Kurikulum K- 13 PAUD}

Standar Tingkat Pencapaian Perkembangan Anak Usia Dini selanjutnya disebut STPPA adalah kriteria tentang kemampuan yang dicapai anak pada seluruh aspek perkembangan dan pertumbuhan, mencakup aspek nilai agama dan moral, fisik-motorik, kognitif, bahasa, sosial-emosional, serta seni (permendikbud No. 137 Tahun 2014).

Program pengembangan nilai agama dan moral sebagaimana dimaksud diatas adalah mencakup perwujudan suasana belajar untuk berkembangnya perilaku baik yang bersumber dari nilai agama dan moral serta bersumber dari kehidupan bermasyarakat dalam konteks bermain. Begitu pula pada program pengembangan fisikmotorik dimaksudkan untuk mewujudkan suasana untuk berkembangnya kematangan kinestetik dalam konteks bermain.

\begin{abstract}
Sedangkan pada program pengembangan kognitif, diwujudkan melalui suasana untuk berkembangnya kematangan proses berfikir dalam konteks bermain. Berikutnya, pada program pengembangan bahasa diwujdukan dalam rangka berkembangnya kematangan bahasa dalam konteks bermain. Kemudian pada program pengembangan sosial-emosional diwujukan melalui suasana untuk berkembangnya kepekaan, sikap, dan keterampilan sosial serta kematangan emosi dalam konteks bermain, dan pada program pengembangan seni diwujudkan untuk berkembangnya eksplorasi,ekspresi, dan apresiasi seni dalam konteks bermain.
\end{abstract}

\section{VideoScribe}

Videoscribe adalah merek dagang dari perusahaan asal Inggris yang bernama Sparkol. Videoscribe adalah alat atau software berbasis animasi yang dapat menghasilkan gambar berantai. Videoscribe diluncurkan pertama kali pada tahun 2012 dan sampai tahun 2014 pengguna videoscribe telah mencapai 25 ribu pengguna dengan lebih dari 135 negara (en.wikipedia.org)

Videosribe dikembangkan berbasis adobe flash yang mampu menghasilkan format video quick time dengan extensi mov dan flash video. Karena luaran aplikasi ini dalam bentuk quick time dimana beberapa pemutar video tidak bisa membaca format tersebut, maka dalam pengembangan ini, file mov 


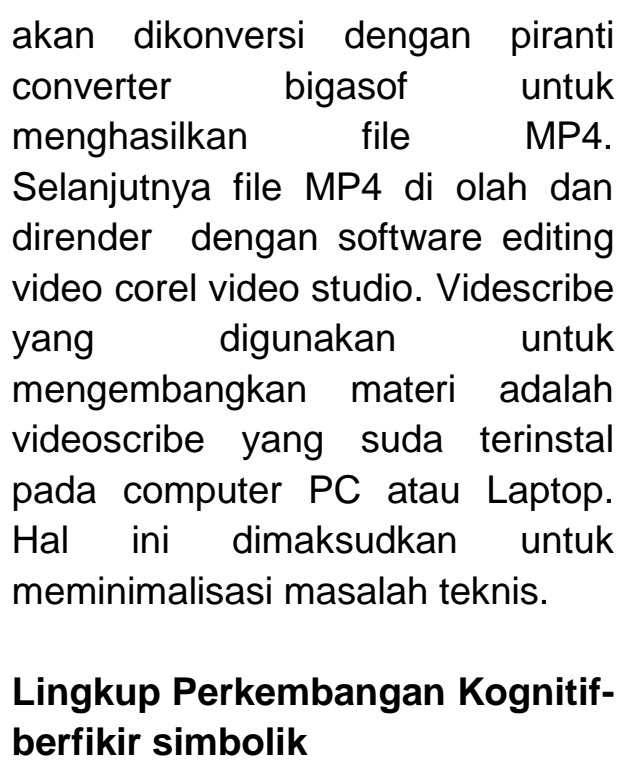

Lingkup perkembangan anak usia dini sesuai peraturan Kemendikbud Nomor 137 Tahun 2014 terdiri dari lingkup perkembangan nilai agama dan moral, fisik-motorik, kognitif, Sosialemosional, bahasa dan seni. Pada lingkup perkembangan kognitif, khususnya sub perkembangan berfikir simbolik anak usia 5-6 tahun, harus mencapai tingkat perkembangan dalam hal, (1) mampu menyebutkan lambang bilangan 1-10, (2) menggunakan lambang bilangan untuk menghitung, (3) mencocokan bilangan dengan lambang bilangan, (4) mengenal berbagai lambang huruf vokal dan konsonan, (5) merepresentasikan berbagai macam benda dalam bentuk gambar atau tulisan, misalnya gambar pensil diikuti tulisan pensil

\section{Model-model Pengembangan Produk}

Model ialah suatu abstraksi yang dapat digunakan untuk membantu memahami sesuatu yang tidak bisa dilihat atau dialami secara langsung. Model adalah representasi realitas yang disajikan dengan suatu derajat struktur dan urutan (Seels \& Richey dalam Oka, G.P.A, 2016). Pengembangan produk pendidikan adalah suatu proses dalam mengembangkan dan memvalidasi produk-produk pendidikan (Ditnaga-Dikti, 2007). Dalam rangka mengembangkan dan memvalidasi produk, maka pengembanganpun memerlukan metode. Metode penelitian ini digunakan untuk menghasilkan produk tetentu, dan menguji keefektifan produk tersebut (Sugiyono, 2009).

Produk-produk

pendidikan/pembelajaran dapat berupa materi ajar, media, instrumen, evaluasi atau model pembelajaran. Model-model pengembang produk memuat langkah-langkah yang sistematis. Menurut Molenda (1996), ada dua macam model yang lazim dikenal dalam pembelajaran, yakni model mikromorf dan paramorf. Mikromorf adalah model yang visual, nyata secara fisik, contohya adalah planetarium dan simulasi komputer, flowchart suatu proses. Paramorf adalah model simbolik yang biasanya menggunakan deskripsi verbal. Model paramorf dibagi menjadi 3 macam, yakni (1) model konseptual, (2) model prosedural, dan (3) model matematik.

Jadi, ciri sebuah model secara umum adalah (1) model memiliki rangkaian elemen atau struktur 
(tipe bisa prosedur, sistem, konten, waktu dan tugas-tugas), (2) Divalidasi atau dibangun berdasarkan hasil penelitian (Ryder, 2001), (3) dikembangkan oleh seseorang atau kelompok orang dengan identitas jelas, (4) preskriptif, seperti istilah Merrill model harus memberikan formula yang teruji untuk di adopsi. (5) model memberikan panduan atau suatu set strategi (Braxton et.al, 1995), (6) sebuah model adalah bagaimana model mengkobinasikan serangkaian strategi yang tampak dari adanya prosedur untuk diimpl ementasikan (Braxton, 1995).

Sedangkan secara khusus, ciri-ciri model tersirat pada masingmasing model itu sendiri. Ciri khusus ini biasanya membedakan antara satu model dengan model yang lain. Ciri yang tampak pada model desain Dick \& Carey dan Kemp misalnya sangat berbeda. Begitupun model pengembangan produk. ciri model umumnya bisa di adopsi, sedangkan model khususnya ada pada masingmasing model. Khususnya pada pengembangan produk, terdapat beberapa jenis model-model pengembangan. Model-model tersebut seperti; (1) Model Alen publikasi tahun 2003 (Allen,2003), (2) Model IMI dari Defense of Army, AS, publikasi tahun 1999 (DoD,199) (3) Model Reeves yang dipublikasikan tahun 1994 (Reeves,1994), (4) Model Cathie Sherwood, Bruce Hodgen, Terry Rout dan Michael Crock, publikasi tahun 2010 (Sherwood,2010), (5)
Model Mallon, publikasi tahun 1995, (6) Model Robler dan Doering yang dipublikasikan tahun 2005 dan (7) Model WaterfallRoyce yang dipublikasikan tahun 1970.

\section{PAUD Lab Ananda Citra Bakti}

PAUD Lab Ananda Citra Bakti adalah sekolah yang berkonsep laboratorium yang digunakan sebagai sekolah laboratorium dari STKIP Citra Bakti. PAUD Lab Ananda adalah sekolah yang merupakan bagian dari sekolah satu atap dan merupakan PAUD Terpadu. Dalam peraturan menristekdikti Nomor 55 tahun 2017 dengan tegas menyebutkan bahwa Sekolah Laboratorium adalah satuan pendidikan yang diselenggarakan oleh LPTK dan/atau bekerja sama dengan LPTK, berfungsi sebagai tempat berlatih mahasiswa Program Sarjana Pendidikan dan/atau Program PPG serta sebagai tempat penelitian, pengabdian kepada masyarakat, dan pengembangan ilmu dan praksis pendidikan

\section{METODOLOGI PENGEMBANGAN}

Model pengembangan produk yang digunakan dalam pengembangan Videoscribe Berfikir Simbolik Representasi berbagai macam benda pada Kelompok Anak Usia 5-6 Tahun Di Paud Lab Ananda Citra Bakti, menggunakan model pengembangan Cathie Sherwood. Dalam dokumen elektronik yang 
berjudul Multimedia Pathways: A Development Methodology for Interactive Multimedia and Online Products for Education and Training, menawarkan enam langkah/fase dalam mengembangkan produk pembelajaran interaktif yang meliputi, 1) Initiation, 2) Specifications, 3) Design, 4) Production, 5) Review and Evaluation, and 6) Delivery and Implementation (Oka, G.P.A, 2016).

\section{Prosedur Pengembangan}

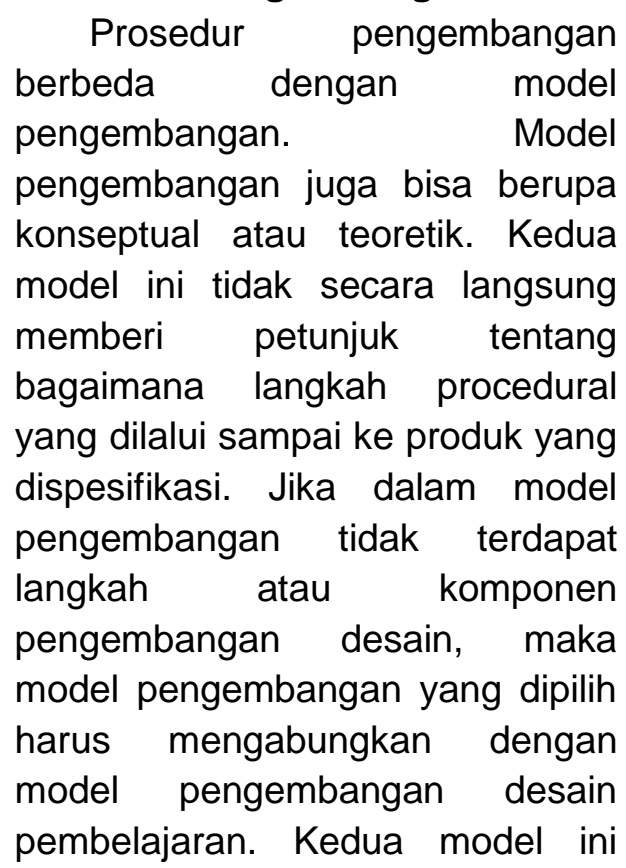

dimodifikasi, karena setiap model memiliki kelebihan dan kekurangan. Adapun prosedur pengembangan yang digunakan adalah (1) menentukan masalah pengembangan, mengembangkan desain pembelajaran, (3) inisiasi produk, (4) spesifikasi produk, (5) desain produk, (6) produksi produk, (7) review \& evaluasi dan (8) delivery \& implementation.

\section{Uji Cova Produk}

Uji coba produk adalah tahap untuk memvalidasi produk yang dikembangkan. Dalam tahap ini yang dilaksanakan adalah membuat skema rancangan/desain uji coba, menentukan subyek uji coba, menentukan jenis data, menentukan metode dan instrument pengumpulan data dan menentukan metode serta teknik analisis data.

Rancangan uji coba produk dalam pengembangan Videoscribe Berfikir Simbolik Representasi berbagai macam benda pada Kelompok Anak Usia 5-6 Tahun Di PAUD Lab Ananda Citra Bakti, seperti tersaji Gambar 1 


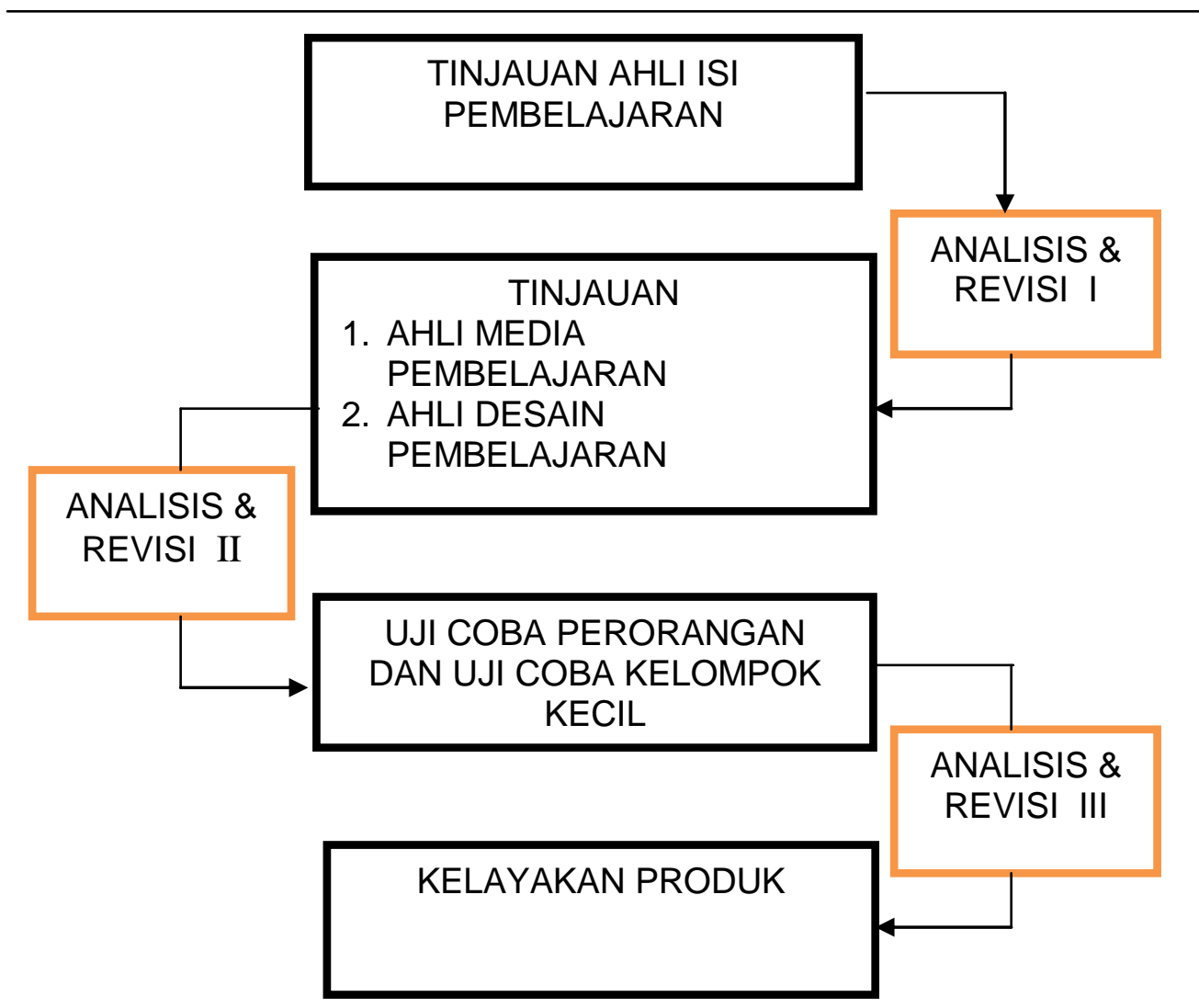

Uji produk terhadap subyek coba akan di review oleh, (1) ahli Isi, Ahli Desain \& Media, (2) Uji coba perorangan, (3) Uji kelompok Kecil, uji ini berjumlah 6 orang anak kelompok usia 5-6 tahun. Data-data yang dikumpulkan dalam penelitian ini mempergunakan metode kuisioner (angket).

Karena subyek coba dalam penelitian ini adalah kelompok anak usia 5-6 tahun, kecuali untuk ahli dan guru, maka yang digunakan metode observasi dan angket dengan instrument daftar cek dan angket. Teknik data yang digunakan dalam penelitian ini menggunakan dua teknik analisis data, yaitu teknik analisis deskriptif kualitatif dan analisis statistik deskriptif kuantitatif. Teknik Analisis deskriptif Kualitatif digunakan untuk mengolah data hasil uji coba dari ahli isi, ahli desain, ahli media, perseorangan dan kelompok. Interpretasi terhadap olah data digunakan untuk merevisi produk video yang sedang dikembangkan. Dasar revisi ini adalah masukan, saran dari beberapa ahli isi, ahli media, ahli desain pembelajaran, anak saat uji coba dan guru kelas.

Sedangkan teknik analisis statistic deskriptif kuantitatif digunakan untuk mengolah data yang diperoleh dari angket dalam bentuk deskriptif prosentase.

Rumus yang digunakan untuk menghitung prosentase dari masing-masing subyek adalah : 


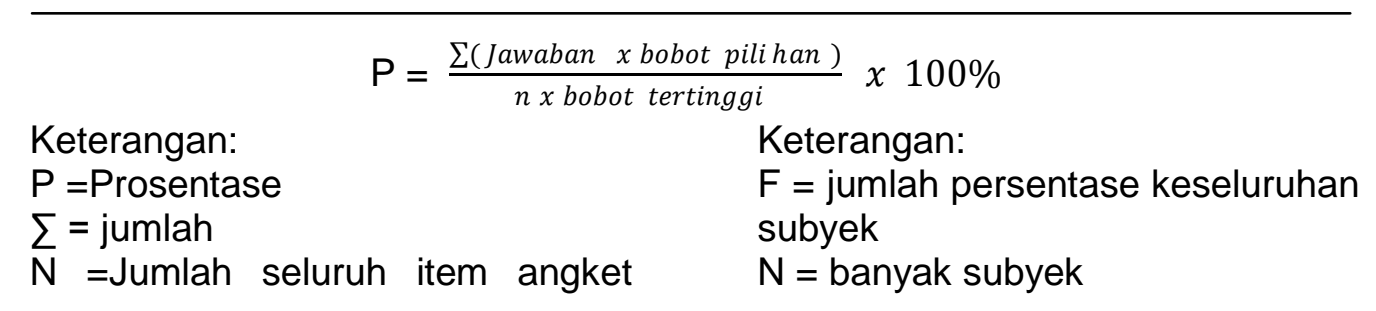

Selanjutnya, untuk menghitung prosentase keseluruhan subyek digunakan rumus:

Prosentase $=\mathrm{F}: \mathrm{N}$
Untuk dapat memberikan makna dalam pengambilan keputusan digunakan ketetapan seperti tersaji pada Tabel 3

Tabel 3. Konversi Tingkat Pencapaian dengan Skala 5

\begin{tabular}{cll}
\hline Tingkat Pencapaian & \multicolumn{1}{c}{ Kualifikasi } & \multicolumn{1}{c}{ Keterangan } \\
\hline $90 \%-100 \%$ & Sangat baik & Tidak perlu direvisi \\
\hline $75 \%-89 \%$ & Baik & Tidak perlu direvisi \\
\hline $65 \%-74 \%$ & Cukup & Direvisi \\
\hline $55 \%-64 \%$ & Kurang & Direvisi \\
\hline $0-54 \%$ & Sangat Kurang & Direvisi \\
\hline
\end{tabular}

\section{HASIL DAN PEMBAHASAN \\ Hasil dan Analisis}

Analisis yang dipaparkan pada draft I pengembangan adalah analisis dari hasil deskripsi data uji ahli isi videoscribe. Angket uji ahli isi yang digunakan dalam penelitian pengembangan ini menggunakan instrument dari hasil penelitian yang di buktikan validitasnya. Komponen, sub komponen dan butir kreteria yang ajukan kepada ahli isi disetujui untuk digunakan dalam penelitian dan pengembangan. Berdasarkan hasil peneliaian ahli isi videoscribe sebagaimana tersaji pada Tabel 1 , dimana rata-rata jumlah skor per item $n-15=69$. Rata-rata jumlah bobot tertinggi dikali jumlah butir $(n-15=75$, ). Dengan demikian prosentasenya $(p)$ dihitung sebesar $=92 \%$. Tingkat pencapaian kualitas isi videoscribe sebesar 92 $\%$ dikonversi dan dimaknai dalam kualifikasi Sangat Baik dengan keterangan isi videoscribe tidak perlu revisi. Berdasarkan hasil uji ahli isi yang diajukan dengan prosentase $92 \%$, ini berarti revisi terkait konten videoscribe tidak perlu dilakukan. Namun demikian item dengan skor perolehan yang belum optimal telah direvisi sesuai masukan.

Analisis yang dipaparkan pada draft II pengembangan adalah analisis dari hasil deksripsi data uji ahli media terhadap videoscribe. Berdasarkan hasil peneliaian ahli media videoscribe sebagaimana tersaji pada Tabel 2, dimana ratarata jumlah skor per item $n-15=71$. Rata-rata jumlah bobot tertinggi dikali jumlah butir $(n-15=75)$. Dengan demikian prosentasenya 
(p) dihitung sebesar $=90 \%$. Tingkat pencapaian kualitas isi videoscribe sebesar $90 \%$ dikonversi dan dimaknai dalam kualifikasi Sangat Baik dengan keterangan isi videoscribe tidak perlu revisi. Kemudian berdasarkan hasil peneliaian ahli desain pembelajaran videoscribe sebagaimana tersaji pada Tabel 3, dimana rata-rata jumlah skor per item $n-15=68$. Rata-rata jumlah bobot tertinggi dikali jumlah butir ( $n-15=75)$, Dengan demikian prosentasenya $(p)$ dihitung sebesar $=94.67 \%$. Tingkat pencapaian kualitas isi videoscribe sebesar $94.67 \%$ dikonversi dan dimaknai dalam kualifikasi Sangat Baik dengan keterangan isi videoscribe tidak perlu revisi. Berdasarkan hasil uji ahli media yang diajukan dengan prosentase $90 \%$ dan ahli desain pembelajaran sebesar $94.67 \%$ ini berarti revisi terkait media dan desain pembelajaran videoscribe tidak perlu dilakukan. Namun demikian item dengan skor perolehan yang belum optimal telah direvisi sesuai masukan.

Analisis yang dipaparkan pada draft III pengembangan adalah analisis dari hasil deksripsi data uji perseorangan dan kelompok kecil terhadap videoscribe. Berdasarkan hasil peneliaian dalam uji perseorangan videoscribe sebagaimana tersaji pada Tabel 4, dimana rata-rata jumlah skor per item $\mathrm{n}-15=14$. Rata-rata jumlah bobot tertinggi dikali jumlah butir (n-15=15). Dengan demikian prosentasenya $(p)$ dihitung sebesar $=93.33 \%$. Tingkat pencapaian kualitas isi videoscribe sebesar 93.33\% dikonversi dan dimaknai dalam kualifikasi Sangat Baik dengan keterangan isi videoscribe tidak perlu revisi. Kemudian berdasarkan hasil peneliaian dalam uji perseorangan videoscribe sebagaimana tersaji pada Tabel 5 , dimana rata-rata jumlah skor per item n-8=64. Rata-rata jumlah bobot tertinggi dikali jumlah butir $(n-8=56)$. Dengan demikian prosentasenya $(p)$ dihitung sebesar $=88 \%$. Tingkat pencapaian kualitas isi videoscribe sebesar 88 $\%$ dikonversi dan dimaknai dalam kualifikasi Baik dengan keterangan isi videoscribe tidak perlu revisi. Berdasarkan hasil uji perseorangan yang diajukan dengan prosentase 93.33\% dan uji kelompok kecil 88 $\%$ ini berarti revisi terkait videoscribe tidak perlu dilakukan. Namun demikian item dengan skor perolehan yang belum optimal telah direvisi sesuai masukan.

\section{Pembahasan}

\section{Dalam} penelitian pengembangan ini dihasilkan dua buah luaran, yaknti (1) Videosrcibe dan (2) tingkat kelayakan produk videoscribe.Oleh karena itu, dalam pembahasan akan dibahas kedua variabel tersebut.

Produk Pengembangan Videoscribe. Videoscribe Berfikir Simbolik Representasi berbagai macam benda pada kelompok anak usia dini usia 5-6 tahun menggunakan format video dengan resolusi 720p. File dalam format MP4 yang dibisa diputar pada komputer dan dapat diputar 
dengan player popular seperti window media player maupun player yang bebasis web seperti yootube.

Hasil evaluasi Formatif Produk Pengembangan. Penilaian ahli isi dalam pengembangan ini adalah untuk mengetahui tanggapan terhadap komponen dan sub komponent dengan atribut pada isi, rancangan dan kualitas teknik.Lebih jelas dipaparkan sebagai berikut. (1) Kesesuian materi dengan $\mathrm{KI}, \mathrm{KD}$, Tujuan dan Idikator mendapat nilai maksimal dikarenakan isi video telah disesuaikan dengan STTPA (permendikbud No 137 Tahun 2014) dan Kurikulum K-13 PAUD (Permendikbud 146 Tahun 2014), (2) Kelogisan susunan isi materi dengan skor maksimal dikarenakan isi telah disesuaikan dengan tingkat perkembangan anak dan Komptensi dasar yang ingin dicapai, (3) Kesesuaian, kecukupan dan kebenaran materi dengan peserta didik juga mendapat sekor maksimal karena isi video sepenuhnya berdasarkan pada Kurikulum K-13, (4) Kemudahan mencerna materi dan tingkat keterbacaan juga mendapat skor maksimal dikarenakan isi video dikembangkan dengan representasi pesan disesuaikan dengan tahapan perkembangan sensori anak, (5) kebiasan dan sistemasi isi juga mendapat skor maksimal dikarenakan isi video direpesentasi dengan teknik moduler, berurutan dengan waktu yang disesuaikan dengan kecepatan anak, (6) sedangkan pada ketersediaan daftar istilah dan daftar pustakan mendapat skor sedang dikarenakan video tidak menyertakan dan mempertimbangkan sisi urgensi dari video disamping itu daftar istilah tidak disediakan, (7) kemudahan memutakhirkan materi memperoleh apresiasi skor maksimal, dikarenakan dengan flatform digital maka video dengan mudah untuk di mutakhirkan, (8) latihan, repetisi dan contoh juga mendapat skor maksimal, dikarenakan isi video telah menyertakan latihan untuk melatih anak begitupun repetisi juga telah disediakan sehingga anak-anak dapat mengulangi kembali pada bagian yang belum dipahami. Hal ini sesuai dengan prinsip pengulangan dan penguatan.

Penilaian ahli media dan Desain dalam pengembangan ini menguji produk media dari komponen dan sub komponen isi, rancangan dan kualitas teknik. Lebih lanjut dipaparkan sebagai berikut. (1) Ketersediaan naskah dengan skor maksimal hal ini dikarenakan videosribe dikembangkan dengan acuan naskah, (2) kelogisan plot cerita video dirancang sesuai urutan perkembangan, oleh karenanya mendapat apresiasi baik, (3)orisinal video juga diapreasi optimal dikarena video dikembangkan dengan ide orisinil, (4)ketepatan penggunaan efek dalam katagori baik, hal ini dikarenakan penggunaan efek hanya pada hal yang perlu untuk menghindari bias pada konten, (5) 
Ketepatan pemilihan pemain, teknik bloking di apresiasi optimal disebabkan videso dikembangkan dengan frame yang mudah dikomposisi, (6)sedangkan pada kualitas video, resolusi juga mendapat skor optimal dikarenakan videso dikembangkan dengan resolusi $720 \mathrm{P}$, ini berarti video telah dikembangkan berdasarkan standar broadcasting, (7) ketepatan penggunaan ritme dan teks juga dirancang sesuai prinsip multimedia berdasar teori Mayer, sehingga skor juga mendapat skor maksimal, (8) sedangkan muatan interaktifitas didesain dari "cue" konten sesuai prinsip multimedia, sehingga diapreasiasi optimal.

Begitupun pula dari ahli desain pembelajaran dimana kelengkapan desain instruksional RPPH mulai dari pemilihan kompetensi dasar, perumusan tujuan yang dirmuskan mengacu aturan ABCD dan rumusan indikator menggunakan kata kerja operasional.Pendekatan dalam video ini menggunakan student centre sehingga mengadopsi perkembangan anak. Begitupula metode yang digunakan, yakni metode simulasi dalam video mampu ditangkap baik oleh anak-anak. Disamping itu konten dalam video ini di organisasi dengan mematuhi prinsip component display teory sehingga representasi pesan bisa maksimal.

Uji perseorangan dalam pengembangan ini adalah mencari tanggapan terhadap komponen dan sub komponen terkait pada kejelasan dan kesalahan

umum.Selengkapnya dipaparkan sebagai berikut. (1) kecukupan materi, lingkungan belajar yang difasilitasi dengan video, keterimaan terhadap video subyek uji coba menyatakan persetujuannya, (2) begitupula terhadap perbaikan media, penyajian pengalaman baru, kebermanfaatan media dan hal baru, responden juga menyatakan persetujuannya. Hanya pada item apakah media ini bisa digunakan tanpa bantuan, responden menyatakan ketidak kesetujuannya. Ini dapat disimpulkan bahwa media video yang dikembangkan repsonden masih memerlukan bantuan orang lain dalam proses pembelajaran.

Uji kelompok kecil dalam pengembangan ini adalah mencari tanggapan terhadap komponen dan sub komponen terkait dengan efektifitas, penampilan dan implementasi videoscribe.Dengan sejumlah delapan item yang diajukan responden menyatakan kesetujuannya terhadap imlementasi videoscribe dalam pembalajaran dan kemenarikannya. Hanya pada perilaku belajar, responden mengharapkan media ini dalam penggunaanya masih menggunakan bantuan seorang guru. Dengan demikian, dari serangkaian penilaian yang dilakukan baik terhadap uji pakar dan uji perseorangan serta kelompok kecil, media videoscribe yang dikembangkan peneliti 


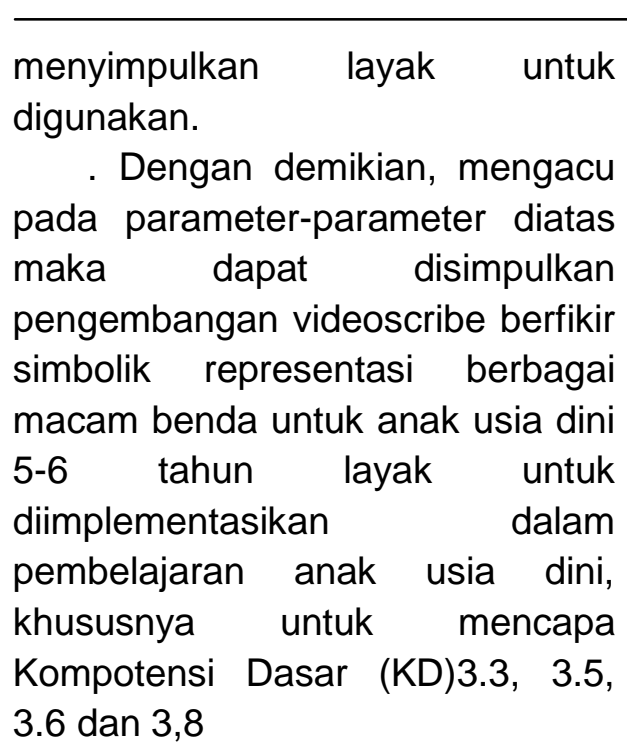

\section{PENUTUP}

\section{Simpulan}

Berdasarkan hasil dan pembahasan seperti yang telah dipaparkan diatas bahwa pengembangan videoscribe berfikir simbolik representasi berbagai macam benda untuk anak usia dini 5-6 tahun dapat diimplementasikan dalam pembelajaran untuk memperkaya strategi penyampaian materi dan untuk mewujudkan lingkungan belajar yang terbuka dan pleksibel. Sebuah lingkungan belajar dengan atmosfir menyenangkan bagi anak. Setidaknya kesimpulan ini ditarik berdasarkan hasil dan analisis parameter ahli isi, ahli media, ahli desain pembelajaran, uji perseorangan dan uji kelompok kecil. Sedangkan untuk melihat efektifitas videioscribe perlu dilakukan uji lapangan yang komprehensif.

\section{Saran}

Agar sukses dalam megimplementasikan model pembelajaran berbasis teknologi, khususnya video pembelajaran, setidaknya ada beberapa komponen yang sangat perlu disiapkan. Komponen itu adalah infrastruktur TIK, fasilitas TIK yang dimilikisekolah, kemampuan penggunaan TIK dikalangan guru AUD, keterampilan literasi media dan teknologi dikalangan guru AUD dan kemampuan inovasi pengembangan yang terus diupayakan untuk ditingkatkan dan dukungan institusi sekolah.

Bagi peneliti lain yang mengembangkan kajian yang sama, sangat dinantikan untuk memperkaya hasil-hasil penelitian dengan payung strategi pembelajaran campuran (blended learning). Sehingga diperoleh komparasi-komparasi yang semakin akurat yang tentunya disesuaikan dengan karakteristik perguruan tinggi dan mahasiswa.

\section{DAFTAR PUSTAKA}

Allen, M. W. (2003). Guide to elearning. New Jersey: John Wiley \& Son Inc

Brame, C. J. (2016). Effective Educational Videos: Principles and Guidelines for Maximizing Student Learning from Video Content. CBE Life Sciences Education, 15(4), es6. http://doi.org/10.1187/cbe.1603-0125.

Ditnaga-Depdiknas. (2007). Metologi Penelitian dan Pengembangan. Makalah. Pelatihan metologi PPKP dan PIPS. Direktorat Ketenagaan 
Direktorat jenderal Pendidikan Tinggi Departemen Pendidikan Nasional. Jakarta

\section{Departement of Depense Hanbook/DoD. (1999). Interactive multimedia instruction (IMI), part 3 of 4 parts, MIL-HDBK-29612-3. N/A: AMSC}

Giannakos, M. C. (2013). Exploring The Video-Based Learning Research: A review of the literature. British Journal of Educational Technology, 44(6).

https://doi.org/10.1111/bjet.120 70.

Heinich, R., Molenda, M., Russell, J. D., \& Smaldino, S. E. (2002). Instructional media and technology for learning, 7th edition. New Jersey: Pearson education, Inc.

Mallon, A. 1995. The Development Process. Tersedia pada http://www.

adrianmallonmultimedia.com/d esignguidelines/devmtpro.htm

Oka, G. P. A. (2011). Pengembangan Bahan Ajar Interaktif Berbasis Component Display Theory (CDT) Pada Mata Kuliah Multimedia Jurusan Teknologi Pendidikan Undiksha.Tesis. Undiksha. Tidak dipublikasikan.

Oka, G. P. A. (2016). Model Konseptual Pengembangan produk pembelajaran: Beserta teknik evaluasi. Yogyakarta: Deepublish-Citra Bakti.

Sugiyono. (2009). Metode penelitian kuantitatif, kualitatif dan R\&D. Bandung: Alfabeta.
Seels, B.B., \& Richey, R.C.(1994). Istructional technology: The Definition and Domain of The Field, terjemahan Yusufhadi Miarso dan Dewi Salma.Washington DC: AECT.

Sherwood, C., Hodgen, B., Rout, T., \& Crock, M. (1990). Multimedia Pathways: A Development Methodology for Interactive Multimedia and Online Products for Education and Training. Impart Corporation. Griffith University.

Reeves. (1994). Multimedia Design Model. Center for Education Integrating Science, Mathematics and Computing (CEISMC), at Georgia Tech's College of Sciences. Tersedia pada

www.ceismc.gatech.edu/MM Tools/MMDM.html

Richey, Rita C. (2007). Design Development and Research: Methods, Strategies, and Issues. Jew Jersey: Lawrence Erlbaum Asssociates.

Peraturan Presidan Nomor 60 Tahun 2013 tentang Pengembangan Anak Usia Dini Holistik-Integratif

Peraturan Menteri Pendidikan dan Kebudayaan Nomor 137 Tahun 2014 Tentang Standar Nasional Pendidikan Anak Usia Dini.

Peraturan Menteri Pendidikan dan Kebudayaan Nomor 146 Tahun $2014 \quad$ Tentang Kurikulum 2013 Pendidikan Anak usia Dini

Peraturan Menteri Riset, Teknologi dan Pendidikan Tinggi Nomor 
55 Tahun 2017 tentang Standar Pendidikan Guru.

Videoscribe. Tersedia online pada url:
https://en.wikipedia.org/wiki/Vi deoScribe. Diakses pada tanggal 10 Agustus 2018 